\title{
Mengomunikasikan Musik kepada Anak
}

\author{
Aziz Taufik Hirzi \\ ABSTRACT \\ Musical lessons are believed helping children to nurture their brains. Depended on the beat, \\ rhythm, and melody, music triggers young nerves to develop and stimulates it to reach maximum \\ impact. In the field of communication education, music was involved in learning process. \\ A method called accelerated learning uses music to create conducive and healthy atmosphere \\ which is necessary in learning process. Within such atmosphere, children develop their creativity \\ to solve their problem. Musical lessons help children to develop their personality, \\ effective communication and social interaction capability, and who knows- \\ find their ways to musical talents.
}

Kata kunci: musik, komunikasi, pendidikan, pembelajaran, anak

\section{Pendahuluan}

Dalam Ensiklopedia Indonesia, seperti dikutip oleh Al-Baghdadi (1991:13), disebutkan bahwa seni adalah penjelmaan rasa indah yang terkandung dalam jiwa manusia. Dilahirkan dengan perantaraan alat komunikasi ke dalam bentuk yang dapat ditangkap oleh indra pendengar (seni suara), penglihatan (seni lukis), atau dilahirkan dengan perantaraan gerak (seni tari, seni drama).

Menurut Quraish Shihab, seni adalah keindahan. Ia merupakan ekspresi ruh dan budaya manusia yang mengandung dan mengungkapkan keselarasan, keserasian, keharmonisan, dan ketepatan yang memesona batin manusia. Ia lahir dari sisi terdalam manusia berupa rasa dan imajinasi yang terekspresi dalam ketrampilan bakat yang indah (Yahya, 2004:161).

Musik adalah suatu rangkaian dari gelombang suara (Tambunan, 2004:13) dalam arti gelombang suara tertentu. Karena gelombang suara garukan kuku jari tangan, misalnya pada papan tulis tidak dapat digambarkan sebagai musik. Lotze dan Herder mengemukakan bahwa musik adalah bahasa alam yang paling alamiah; dan bahasa alam dari pada gairah hidup dan bahasa mantra dari jiwa manusia (Hardjana, 1983:41).

Pada kenyataan seperti itulah keindahan musik berada, karena musik melambangkan diri manusia sendiri yang mempertaruhkan emosi dan vitalitas manusia yang sekaligus bisa memotivasi manusia dalam mendengar, mencipta, dan memainkan musik karena ingin melihat dirinya sendiri.

Seni musik adalah seni yang berhubungan dengan alat-alat musik dan irama yang keluar dari alat musik. Dalam perjalanannya, seni musik dapat berpadu dengan seni suara (vokal), sehingga timbul suara oral (vokal) yang diiringi alat musik. Iringan musik saja beragam, bergantung pada jenis lagu yang disesuaikan dengan budaya dan selera manusia.

Seorang filsuf legendaris, Plato menuturkan bahwa "Musik merupakan hukum moral. Dia memberi jiwa kepada alam semesta, memberi sayap 
kepada pikiran dan imajinasi, memberi keceriaan pada kesedihan, memberi kegembiraan dan kehidupan kepada segala hal. Musik adalah esensi keteraturan dan membawa pada semua hal yang baik, adil, dan indah" (Merritt, 2003:1).

Musik bagi para penggemar tidak hanya sekadar hiburan yang cepat lepas dari memori, tapi boleh jadi merupakan suatu sarana yang memberi insipirasi, motivasi, dan dedikasi. Musik bisa memberi insipirasi manakala manusia itu membayangkan apa yang terjadi pada isi lirik itu pada masa lampau dan masa kini serta masa yang akan datang; bisa memberi motivasi manakala manusia itu merasakannya sebagai penggugah semangat, atau bisa memberi dedikasi manakala memperhatikan liriknya yang berisi petuah-petuah moral.

Musik juga bisa membangun citra diri yang membuat orang semakin cinta lingkungan manakala menyaksikan lingkungan alam yang rusak. Dengan pengaruh musik, seseorang ingin melihat dan merasakan suasana yang indah, romantis, dan mempesona.

Tidak hanya itu, musik dapat pula merupakan pelampiasan kekesalan manakala sesorang berada pada masa "pancaroba" atau masa "kritis". Penumpahan kekesalan ini biasanya tersalur lewat musik keras atau amat keras/ingar bingar (rock/ hardrock).

Musik lembut, semi lembut, keras, semi keras, atau datar, atau musik dengan aliran yang beraneka warna akan memberi makna bagi diri seseorang manakala ia meresapinya dalam-dalam. Musik tidak cukup didengar dan dimainkan, tapi peresapan dan penghayatan itulah yang akan membantu mempengaruhi watak pribadi. Di sinilah komunikasi berlangsung antara seseorang dengan musik yang didengar atau dimainkannya.

Seorang anak yang pandai dan serba ingin tahu, terutama anak yang gemar dan punya minat terhadap musik, ketika ia mendengar dan atau memainkan alat musik akan "tenggelam dalam dunia fantasinya" seolah-olah hidup di alam lain yang terasa lebih indah dan menyenangkan. Komunikasi intrapersonal berjalan dengan baik meski kemudian ia akan merasakan perbedaan yang tajam antara dunia nyata dengan dunia "khayalnya". Sebaliknya, seorang anak yang sama seperti tadi, pandai dan serba ingin tahu, suatu saat akan mengalami kejadian lain "merasa sedih", karena apa yang diinginkan dan dirasakannya tidak pernah ditemukan. Ia kehilangan komunikasi dengan dunia "harapannya'.

Orang tua yang ekonominya mapan dan peduli seni mengkursuskan anak-anak mereka ke sekolah musik dengan harapan anak-anak itu merasakan dan menyadari betul akan pentingnya pemeliharaan jiwa, karena sekarang ini semakin banyak orang yang menyadari pentingnya makanan sehat, tetapi mereka tidak tahu "makanan" yang baik untuk pencernaan jiwa, yakni pembelajaran melalui musik (mendengarkan/ memainkan alat musik).

Apabila nutrisi berguna untuk membuat otak lebih sehat dan bugar, musik membuat otak lebih prima. Saat belajar atau bekerja gerakan otak tidak merasa "terpaksa". Sebaliknya, saraf-saraf dan seluruh sistem di dalam otak sudah prima dan siap bertugas. Musik membantu menyiapkan jalur-jalur jalannya informasi di otak.

Kehadiran sekolah musik yang kini banyak tersebar di berbagai tempat adalah salah satu bagian dari upaya untuk menampung dan menyalurkan para penggemar musik, terutama anak-anak, baik atas kesadaran/kemauannya sendiri maupun atas dorongan orang tuanya atau dua-duanya kemauan dan dorongan.

Musik tampaknya sudah menjadi kebutuhan yang diperhitungkan banyak orang, tertutama penggemar, bahkan orang tua yang tidak sempat/ tidak mampu mengkursuskan anak-anak mereka ke lembaga formal (sekolah musik) beriinisiatif memberikan alat-alat musik yang kira-kira cocok untuk usia anak dengan biaya terjangkau.

Besarnya perhatian orang tua terhadap anak pada musik, karena tidak dapat dilepaskan dari keyakinan orang tua yang mempercayai manfaat musik bagi pengembangan diri anak, antara lain bahwa musik dapat menyeimbangkan suasana hati, dapat mengembangkan kreativitas, dapat menemukan karakter diri sendiri dan musik dapat memberdayakan ingatan yang tajam dan jernih. 
Berkenaan dengan uraian di atas, penulis ingin menyampaikan beberapa hal ihwal bilamana dan di mana musik itu diajarkan pada anak; bagaimana caranya memberdayakan diri anak itu melalui seni musik; dan jenis musik apa yang relatif sesuai dengan usia anak dalam membantu pengembangan diri anak itu.

\section{Aktivitas Seni Musik dan Pemberdayaan Anak}

\subsection{Bilamana dan di mana Musik itu Diajarkan pada Anak?}

Anak yang cerdas, patuh, kreatif, dan sehat mental-fisik adalah dambaan orang tua. Apa pun yang dilakukan anak-anak, menyenangkan atau tidak, adalah suatu bentuk perbuatan yang tidak dapat disalahkan. Yang penting, bagaimana orang tua mampu menciptakan suasana anak yang nyaman, bebas dari rasa cemas dan takut. Jiwa perasaan anak dipahami dan nafsu orang tua terkendali.

Dorongan pada anak untuk menjadi diri mereka sendiri lebih penting dari sekadar mengharapkan anak untuk mendapatkan nilai A. Anak-anak yang awalnya belajar melalui proses bawah sadar dan pada saat mereka duduk di kelas 2 Sekolah Dasar sudah mulai menggunakan pikirannya. Mereka adalah anak-anak yang amat membutuhkan perhatian.

Kemampuan berpikir mereka yang baru saja mekar kadang-kadang terkalahkan oleh perasaan takut, ragu, dan cemas, yang apabila perasaan "minus" ini terus menerus menghantui mereka, dikhawatirkan akan menggangu perkembangan jiwanya bahkan lebuh jauh bisa jadi menghambat karier dan masa depan anak.

Mengerjakan pekerjaan rumah, malas; petuah orang tua tidak dihiraukan, gaul dan kerjasama kurang; apriori dan mudah tersinggung yang sudah merupakan bagian dari kehidupannya dicoba untuk dihindari.

Oleh karena itu, orang tua atau guru/pendidik perlu "mendekati" anak dengan mengajarkan kreativitas, penghargaan diri, ramah, dan kemampuan bersosialisasi dengan lingkungan.
Juga memahami cara mengatasi stres dan meningkatkan keterampilan dasar anak. Yang jelas, pendidikan itu lebih menekankan pada masalah kemanusiaan yang terkait langsung dengan masalah sehari-hari dan cara menangani permasalahan tersebut secara bersama-sama (Levine dalam Merritt, 2003:48).

Dalam kaitan ini, musik digunakan sebagai sarana penghubung antara pikiran dan hati, sebagai alat pengungkapan diri yang bisa membantu anakanak melakukan semua itu.

Dengan kegiatan musik, anak-anak akan memahami perasaan orang-orang disekitarnya; orang tua, famili, teman, dan siapa saja yang berada dalam pikirannya. Juga, mereka (anak-anak) akan memahami cara yang benar dan sempurna tidak hanya pada satu hal, baik dalam berpikir maupun bertindak.

Dalam hal ini, metode pencitraan musik mengajarkan kepada anak-anak bahwa pikiran kita hanyalah cermin keunikan diri kita. Dengan musik anak-anak bisa berfantasi, bebas membayangkan apa saja yang menjadi pengalaman dan harapannya di masa mendatang. Ceria-murung; lincah-kalem; tertawa-menangis; suka-duka, adalah bagian dari kelucuan anak yang patut dipahami orang tua. Keadaan anak-anak tersebut akan terekspresikan melalui musik, apakah ketika anak mendengar suara musik atau ketika memainkan alat musik.

Seorang anak seperti dikatakan Merritt (2003:49), yang imajinasinya terangsang oleh musik menorehkan sebuah tulisan yang merupakan kenangannya. Menurut Merritt,

Ketika musik mulai bermain, rasanya menyenangkan, seperti pelukis yang menggambar dengan goresan-goresan panjang dan cepat, sebuah pancuran yang memancarkan air, pohon palem yang melambai ditiup angin, seekor kucing bermain dengan gulungan benang, membentuk benang kusut, kusut, dan lebih kusut, seekor kuda berlari di tepi pantai, berjuang untuk keluar dari air. Pelukis itu kembali pada musik. Lagu-lagu ini seperti pelajaran pertama saya tentang cara melompat di kelas balet. Ini adalah bagian saat saya terjatuh.

Menyimak apa yang terjadi pada anak, 
menunjukkan bahwa suasana lingkungan yang nyaman dan ekspresi kebebasan mereka serta terawangannya pada keindahan adalah bagian dari kebebasannya berangan-angan.

Georgi Lozanov, perintis metode bebas stres accelerated learning, membagi pembelajaran menjadi 3 (tiga) bagian: ingatan dan intelektual; pendidikan; dan kesehatan (Merritt, 2003:49). Karya Lozanov yang revolusioner di bidang pendidikan menunjukkan perlunya para pendidik memberikan lebih banyak perhatian pada kesehatan mental dan emosi. Penelitiannya menunjukkan bahwa sekolahlah penyebab utama stres terbukti dengan meningkatnya kasus-kasus kejiwaan, kelelahan, dan penyakit lain yang menimpa anak-anak di sekolah. Lozanov merumuskan istilah didactogency, yakni penyakit atau tertekannya perkembangan anak-anak akibat pendekatan guru yang kurang bijaksana.

Lozanov juga menciptakan metode pengajaran dan pembelajaran yang baru, yang diberi nama suggestopedia, karena metode ini didasarkan pada ilmu pemberian saran (science of suggestion). Lozanov menunjukkan bahwa mengetuk "kapasitas cadangan otak", yaitu kira-kira 96\% kapasitas otak yang biasanya tidak kita gunakan, tidak hanya terkait dengan beragamnya materi yang diajarkan, tetapi juga terkait dengan berkembangnya kepribadian yang sehat, kesehatan, dan kebahagiaan fisik anak.

Dampak terapi musik apabila dipadukan dengan seni, drama, dan konsentrasi dalam suasana santai, mampu mengaktifkan kapasitas paraconcious, yaitu semua tingkat kejiwaan yang tidak sadar, yang tidak terbatas. Metode ini yang biasa disebut metode accelerated learning, terkait dengan terciptanya lingkungan yang syarat dengan pemahaman psikologis, yang bertujuan membebaskan dan merangsang kepribadian yang dimulai secara dini pada masa kanak-kanak.

Dengan demikian, pengajaran seni musik sebaiknya diberikan sejak dini, baik pada masa janin dalam kandungan maupun pada masa usia anak dalam buaian, atau masa anak sampai usia 13 tahun.

Tamam Hoesein (Republika, 08 September
2003), seorang guru dan pelatih musik yang telah menghasilkan para musisi dan penyanyi terkenal, berdasarkan pengalamannya secara spesifik menyebutkan bahwa pengajaran musik pada anak sebaiknya diberikan sejak anak sudah bisa berkonsentrasi selama 10 atau 20 menit pada musik atau kira-kira anak berusia 3-4 tahun, karena pada usia tersebut anak-anak relatif sudah bisa diberi pelajaran musik secara serius.

Gilang Ramadhan (Republika, 11 Mei 2003:14) lain lagi. Ia dan istrinya, Shahnaz Haque, sepakat, paling tidak memperkenalkan instrumen musik dan bunyi-bunyian yang bernuansa "musik"sejak anak-anak berumur satu tahun. Hal ini dilakukan sebagai "pengulangan" yang pernah ia alami pada waktu kecil dari didikan orang tuanya, Ramadhan $\mathrm{KH}$.

Di samping itu, dapat pula diajarkan bagaimana anak belajar musik pada saat bermain/ ceria (di sela-sela bermain), pada saat belajar/serius (di sela-sela belajar) dan juga bagaimana orang tua memberikan arahan pelajaran musik pada saat anak dalam suasana bosan, jenuh, kurang perhatian, dan tidak menyenangkan, di rumah, di sekolah, di tempat rekreasi, dan di tempat latihan/kursus musik.

\subsection{Memberdayakan Diri Anak dengan Musik}

Orang tua manapun pasti mengharapkan pertumbuhan anak (secara fisik) normal dan perkembangan jiwanya wajar. Anak itu pinter, cerdas, lincah, lucu, dan sejumlah harapan yang hampir tidak pernah ada batasnya. Mendekatkan anak dengan musik sebenarnya bukan satusatunya cara yang ampuh dan mampu untuk menyelesaikan segala perkara yang berkaitan dengan perilaku anak, tapi dengan cara ini sekurang-kurangnya perilaku anak akan mulai terbentuk.

Sebelum orang tua membimbing dan mengarahkan anak "berdaya", terlebih dahulu orang tua perlu memahami apa yang bisa dilakukan orang tua dalam menciptakan keamanan dan kebebasan psikologis guna membentuk suasana belajar yang menyenangkan pada anak. Agar anak- 
anak senang, Ekomadyo (2005:19-20) menawarkan 6(enam) cara :

(1) Membangun empati, yaitu bagaimana orang tua memahami apa yang dirasakan anak, mendengarkan apa yang diutarakan dan dikeluhkan, serta menjalin kedekatan.

(2) Menjalin kebersamaan, yaitu bagaimana orang tua membangun suasana yang mengesankan seolah-olah orang tuanya menjadi teman bermain anak. Anak dan orang tua saling bertoleransi.

(3) Membangun rasa memiliki, yaitu, orang tua melibatkan partisipasi anak dalam proses pengajaran atau pertanyaan orang tua ketika mengajari anak supaya dikaitkan dengan dunia keseharian anak. Di samping itu, anak diberi keleluasaan untuk berekspresi.

(4) Mendorong kebebasan berekspresi. Anakanak diberi keleluasaan berekspresi sebagiai upaya untuk meningkatkan kreativitas anak.

(5) Pendampingan. Pendampingan dilakukan untuk memberikan kenyamanan pada anak. Orang tua dapat mengarahkan aktivitas anak dan memberitahu anak mana yang boleh dan mana yang tidak.

(6) Mengembangkan komunikasi efektif, artinya orang tua harus berupaya agar pesan yang diutarakannnya benar-benar mengena dan membuat anak tertarik, sehingga minat belajar dan upaya anak untuk mengembangkan potensi pribadinya cukup kuat.

Selain itu, orang tua perlu memahami manfaat musik dalam kehidupan (Merritt, 2003:6) sebagai bekal yang akan ditularkan kepada anak-anak pada saatnya. Manfaat musik dimaksud adalah :

(1) Menurunkan stres dan mendukung proses penyembuhan.

(2) Menemukan aspek-aspek kepribadian yang tersembunyi: pribadi yang berani berisiko, yang gembira, dan bebas.

(3) Memberi sudut pandang berbeda dalam meninjau kehidupan dan memberdayakan, sehingga mampu mengatasi konflik batin dan mengatasi berbagai rintangan hidup.

(4) Memperkaya hidup dan memperluas dunia dengan keindahannya
(5) Meningkatkan pembelajaran dan daya ingat

(6) Merangsang kreativitas dan imajinasi

(7) Mampu menjembatani komunikasi orang tuaanak dan bisa membantu anak-anak dalam meningkatkan gambaran diri mereka.

(8) Membantu kesantaian, menyegarkan, dan menenangkan.

Merujuk dari apa yang dikatakan Merritt, sebenarnya orang tua dapat mempertimbangkan mengenai pentingnya anak-anak mereka "bergaul dengan musik", karena musik itu jauh lebih bermanfaat dari sekadar bermain "game" hiburan dan nonton film kartun di televisi yang banyak menyita waktu dan sekadar untuk membuat anak “anteng"(mengasyikan).

Agar anak-anak perhatian, orang tua dapat memulai pengajaran musik dengan menghadirkan terlebih dulu berbagai jenis alat musik apa saja sesuai dengan kemampuan. Anak-anak kemudian diarahkan untuk memilih salah satu yang menjadi minatnya. Setelah itu baru orang tua memusatkan perhatian pada salah satu alat musik yang mereka minati. Selain itu, tidak sekadar alat musik, suara musik instrumen dan nyanyiannya yang berlirik juga diperdengarkan kepada anak.

Apabila anggaran mencukupi, ada baiknya anak-anak dimasukkan ke sekolah musik atau latihan di rumah secara sendiri-sendiri atau berjamaah dengan temannya, bisa juga latihan sekaligus "show" di alam terbuka, seperti di gunung dan pantai, di depan keluarga, di tempat pesta, atau di mana saja yang bisa menggugah kreativitas.

Kursus dan latihan/show sebaiknya didampingi pengajar/pelatih yang memahami musik berikut notasi lagu, atau lebih bagus lagi dengan teori-teori musik.

Dampak dari kursus/latihan, terserah pada anak, apakah akan menjadi pemusik, penyanyi, guru musik, komposer, atau apa saja. Yang penting, kemandirian, kepekaan, kehalusan budi, ketulusan hati, dedikasi, kesantunan, kesetiakawanan, semangat, dan apa saja yang terbaik bagi anak bisa menyirami nurani/jiwa anak.

Dengan musik, anak-anak bisa mengenal diri sendiri dan lingkungan, karena musik dapat 
menuntun anak-anak pada berbagai situasi terutama pada saat sendiri (kesendirian). Di samping itu, musik bisa mencegah amarah dan mengurangi stres, karena dengan mendengar suara musik dan memainkan alat musik. ekspresi kekesalan dan perasaan tertekan bisa tertumpahkan.

\subsection{Musik dan Pengembangan Diri Anak}

Apabila anak-anak bernyanyi, bersenandung, dan bermain alat musik biarkan saja, itu tanda menyukainya. Turunkan suara vokalnya apabila terlalu keras (terlalu berani) dan naikkan suara vokalnya apabila terlalu pelan (malu-malu). Orang tua berkewajiban meluruskan, bukan melarang, karena larangan akan menimbulkan rasa tertekan pada anak. Yang dibutuhkan anak pada saat itu adalah bimbingan dan arahan atau curahan kasih sayang yang dirasakan anak sebagai motivasi dalam pengembangan dirinya.

Orang tua tidak cukup melonggarkan anak asal bernyanyi atau bermain musik, tapi pemahaman orang tua terhadap minat dan bakat anak perlu dimiliki. Orang tua tidak membiarkan anak-anak bernyanyi atau bermain musik sendirian, sementara orang tua asyik dengan kegemarannya nonton sinetron atau lagu dangdut dan tariannya yang bergaya Inul. Saling membiarkan akan menyebabkan terputusnya komunikasi orang tuaanak atau kurangnya perhatian ini akan menimbulkan dampak yang kurang baik pada anak.

Oleh karena itu, pengajaran musik tidak sekadar penyaluran hobi dan minat-bakat anak, lebih dari itu adalah suatu upaya untuk membentuk kepribadian anak.

Sebelum sampai pada jenis musik apa yang relatif cocok bagi anak, terlebih dahulu akan diuraikan mengenai berbagai jenis musik yang perlu dikenal dan pengaruh musik pada dunia anak.

\subsubsection{Mengenal Jenis Musik}

Dari sekian jenis musik, ada beberapa yang patut kita ketahui, diantaranya adalah; musik klasik, musik New Age, musik jazz, dan musik rock/ hardrock.

\section{(1) Musik Klasik}

Musik klasik atau musik yang berusia tua ini adalah musik yang mengutamakan keteraturan, kecermatan, dan ketelitian. Aransemennya mengandalkan kesatuan yang tertuju pada pengembangan. Harmoni, dinamis, perpaduan bunyi lembut, keras dan agak keras, dengan nada yang turun-naik adalah bagian dari musik ini.

Musik klasik kadangkala terkesan elit, sulit, dan pelit. Elit karena para peminatnya orang-orang tertentu yang jumlahnya terbatas. Sulit karena ketika mendengarkan suara musik dan memainkan alat musik relatif serius, dan pelit karena pendengar dan pemain musik seperti mahal senyum.

(2) Musik "New Age"

Guru-guru sekolah di USA berpendapat bahwa musik New Age merupakan musik pilihan yang berguna diputar di kelas, karena dapat membantu siswa bersantai atau menjernihkan pikiran mereka pada saat pindah dari satu kegiatan ke kegiatan lain. Tema musiknya sering bersifat universal dan global. Misalnya, tentang lingkungan hidup dan etnis. Struktur lagunya sederhana, sering tanpa arah, serta garis melodi yang jelas, dan kadang-kadang mencerminkan keterkaitan dengan alam terbuka. Selain itu, kadang-kadang musik New Age menggunakan instrumen dan bunyi-bunyian aneh yang khas dan tentu berbeda dengan jenis musik lainnya.

Di USA, jenis musik ini sedang naik daun dan populer dan terutama digunakan untuk relaksasi dan meditasi.

\section{(3) Musik Jazz}

Musik jazz adalah kombinasi dari kultur Afrika dan Eropa, tetapi berkembang di Amerika Serikat. Aliran ini agak unik karena dapat mewujudkan perpaduan suara pedesaan dan perkotaan. Kelompok musik terkenal yang dicatat dalam "petualangan" jazz ini adalah New Orleans Dixieland, kelompok sejuk dari New York dan Jazz tradisional Chicago pimpinan Nick Lakocca yang bernama Original Dixieland Jazz Band.

Musik jazz ini akornya miring-miring, kaya improvisasi dan kreasi individu. Musik ini sangat indah dan bisa dinikmati oleh siapapun yang 
gemar. Tetapi kadang-kadang sinkopasi dan ritme musik jazz yang tidak teratur ini tidak sesuai dengan pembelajaran dan terapi.

(4) Musik Rock/Hardrock

Qobla rock adalah blues. Artinya, perkembangan rock berawal dari blues. Musik rock dikatakan irama kota yang diciptakan oleh para musisi yang juga disebut pelopor rock" $n$ "roll seperti Little Richard dan Chuck Berry.

Para musisi terilhami oleh perpindahan orang negro Amerika setelah Perang Dunia II dari pedalaman ke kota-kota di Utara seperti Chicago dalam upaya untuk mencari pekerjaan dan melarikan diri dari rasialisme. Ciri-ciri musik rock adalah ingar bingar, meriah, keras. Meski di satu sisi, orang tua terutama ibu-ibu merasa khawatir akan dampak musik ini, tapi di lain sisi, dapat membangkitkan semangat dan menggugah orang dari "keloyoan dan kelayuan".

\subsubsection{Pengaruh Seni Musik terhadap Dunia Anak}

Seorang anak akan melakukan proses pengolahan informasi (menerima informasi, mengolahnya, menyimpannya, dan menghasilkannya kembali) ketika dengan kesungguhannya mendengar dan atau memainkan alat musik. Proses pengolahan informasi yang juga disebut komunikasi intrapersonal ini meliputi sensasi, persepsi, memori, dan berpikir. Sensasi adalah proses menangkap stimuli. Persepsi adalah proses memberi makna pada sensasi sehingga manusia memperoleh pengetahuan baru. Persepsi mengubah sensasi menjadi informasi. Memori adalah proses menyimpan informasi dan memanggilnya kembali. Berpikir adalah mengolah dan memanipulasikan informasi untuk memenuhi kebutuhan atau memberikan respons (Rakhmat, 1996:49).

Mendengar atau memainkan alat musik bisa memperkuat gambaran diri dan mendorong kita untuk menjadi diri sendiri. Sekali kita merasakan, pikiran dan hati kita bertemu menjadi satu kesatuan. Empati berubah menjadi peduli dan peduli berubah menjadi perasaan cinta.

Musik mengembalikan kesadaran kita pada keutuhan diri dan menunjukkan kepada kita bahwa perkembangan kita sebagai manusia bergantung dari sikap saling mencintai damn saling mendukung pada tingkatan yang paling dalam.

Gilang Ramadhan (Republika, 11 Mei 2003) dalam pengalaman masa kecilnya menuturkan kehangatan orang tuanya yang membantu Gilang menemukan sendiri bakat dan kemampuannya dalam musik. Selama menjadi anak, Gilang menemukan bentuk kasih sayang dan pemahaman orang tua terhadap karakter dirinya dan kehangatan lain yang mendorong pencapaian prestasi di semua bidang. "Dengan itu saya bisa mengerti bagaimana menempatkan diri di lingkungan," ujarnya.

Dalam Republika (11 Mei 2003), dikisahkan, seorang anak siswa SMP kelas 2 di Jakarta, bernama Annisa (13 tahun), yang belajar sambil diiringi musik. Annisa, seorang pecinta berat musik ini menyukai lagu-lagu dari boy Band seperti Westlife dan Vlue, yang biasa menemaninya saatsaat dia belajar.

Apa yang dialami Gilang dan Annisa tentu menarik dan merupakan contoh nyata dari aktivitas musik. Yang jelas, anak-anak tidak perlu menunggu dewasa untuk mengenali dan menyerap berbagai aspek kepribadian melalui musik. Dengan Metote Pencitraan Musik (MPM), anak-anak diarahkan pada upaya untuk membangun penghargaan diri yang bisa diterapkan di rumah dengan cara menyenangkan, santai, dan mendidik. MPM bisa membantu anak-anak menyerap informasi pada tingkatan yang lebih dalam, sehingga mereka bisa mengenal diri mereka dengan cara yang baru.

"Ternyata, anak-anak cukup apresiatif terhadap musik klasik. Jika Twilite Orchestra (TO) tampil di depan anak-anak, tak satu pun dari mereka yang tertidur saat musik dimainkan. Bahkan, mereka bergairah sekali. Hal itu tampak dari sikap mereka yang tertib, menyimak, tidak ada yang ngobrol ataupun bercanda. Dan begitu satu nomor selesai, mereka bersorak. Baik anak TK maupun SD sama saja.” demikian kata Addie M.S. (Merritt, 2003:xi).

Clynes dalam Merritt (2003:129) berhasil mengembangkan sebuah ilmu pengetahuan baru yang dinamakan sentics - yaitu studi tentang komunikasi emosi. Clynes membagi emosi manusia 
menjadi tujuh emosi dasar yang dinamai "bentuk dasar" (essentic form), yang terdiri dari: cinta, benci, hormat, sedih, marah, gembira dan seksual. Pada awal kehidupan, setiap emosi dikodekan oleh sistem sarafke dalam otak dan setiap emosi terkait dengan, atau bisa dipicu oleh sebuah pola khusus. Clynes melakukan uji coba terhadap beberapa relawan, meminta mereka untuk merasakan emosi tertentu sambil meletakkan jari mereka di atas sebuah alat pengukur tekanan. ketika intensitas tekanan diplot ke dalam bentuk grafik, pola-pola yang muncul serupa dengan pola emosi yang dipicu oleh musik tertentu. Sebaliknya, musik yang mencerminkan emosi tertentu mengaktifkan bentuk dasar tertentu di dalam otak. Pola-pola yang muncul ternyata seragam, tanpa membedakan budaya maupun jenis kelamin.

Dahulu, pertanyaan tentang bagaimana musik dikomunikasikan yaitu bagaimana musik mengubah kondisi kita dan memberi kita gagasan - harus dijawab oleh para ahli estetika atau oleh kritikus musik. Sekarang, kita bisa menafsirkan bahasa musik secara ilmiah dengan mengacu kepada bentu-bentuk dasar.Seorang komposer yang ingin agar bagian dari musik yang diciptakannya mencerminkan kegembiraan, bisa melakukan hal itu. Seorang musisi yang memahami maksud sang komposer bisa menyuntikkan kegembiraan sehingga para pendengar menjadi peka terhadap penampilannya dan merasakan kegembiraan yang diciptakan dalam bentuk musik, ratusan tahun sebelumnya. Semua ini bisa dilakukan melalui fungsi dan stabilitas bentuk esentik.

Bentuk dasar merupakan elemen musik, seperti juga surat yang merupakan elemen bahasa. Semakin murni seorang musisi bisa mereproduksi bentuk dasar tersebut, semakin besar kekuatan musik tersebut untuk menjadi cerminan dan ungkapan emosi. Setiap kali kita mendengarkan musik indah yang dibawakan oleh seorang musisi andal, perasaan kita berkata bahwa sang musisi mampu menangkap detak nadi sang komposer. Kita merasa tersentuh oleh musik. Musik menyentuh kita secara sangat dalam dan mengilhami kita dengan cara yang sulit diungkapkan dengan kata- kata.

Mengutip hasil penelitian neurologis yang dilakukan Jean Claude dari University of Caen (Republika, 09 Mei 2004), Addie M.S. mengemukakan terjadi peningkatan aktivitas bagian frontal otak kanan dan bagian temporoparietal otak kiri pada anak yang mendengarkan musik klasik gubahan Mozart. Korteks bagian frontal berkaitan dengan fungsi intelektual, dan korteks lobus temporalis berkaitan dengan fungsi integrasi.

Dengan teraktifkannya bagian-bagian otak tersebut, maka simpul-simpul di otak yang berperan dalam proses berpikir menjadi terlatih pula. Musik klasik yang mengandung komposisi nada yang berfluktuasi antara nada tinggi dan nada rendah akan merangsang kuadran $\mathrm{C}$ pada otak. Sampai usia 4 (empat) tahun kuadran B dan C pada otak anak akan berkembang hingga $80 \%$ (persen) dengan musik.

Pengaruh ini sebenarnya tidak dimulai sejak anak. Sejak bayi dalam kandungan (janin) sudah mulai mengadakan proses belajar, dan pada usia 6 (enam) bulan sudah mendengar suara-suara dengan jelas. Thomas Verny dalam bukunya yang berjudul The Secret Life of the Unborn Child (dalam Merritt, 2003:69) menggambarkan pengaruh berbagai jenis musik terhadap janin di dalam kandungan berdasarkan uji cobanya dengan menggunakan alat ukur. Hasil uji coba menunjukkan bahwa Vivaldi dan Mozart merupakan komposer favorit para calon bayi.

Dalam sebuah penelitian yang dipimpin Verny tadi terungkap bahwa “... ketika komposisi karya kedua komposer (Vivaldi dan Mozart) diputar, detak jantung janin biasanya menjadi lebih stabil dan melambat. Sebaliknya, hampir semua janin terganggu saat mendengar komposisi karya Brahms dan Bethoven, atau semua jenis rock. Janin-janin itu akan menendang dengan keras saat musik tersebut diperdengarkan di hadapan ibu yang sedang mengandung."

Penelitian Lozanov (Merritt, 2003:75) menunjukkan bahwa pembelajaran yang dilakukan dalam suasana santai dan menyenangkan bisa disamakan dengan obat yang mudah ditelan. Ketika guru-guru di USA mulai melakukan 
percobaan serupa dengan memutar beberapa jenis lagu yang beraliran New Age, Lozanov meminta agar para guru juga menguji efek kejiwaan yang ditimbulkan oleh musik tersebut sebelum menyimpulkan bahwa musik pilihan mereka memberikan dampak yang sama dengan jenis musik yang dipilihnya.

Beberapa lagu rock karya The Beatles, Stevie Wonder, dan lagu-lagu "lembut" karya musisi saat ini memang cukup "nyaman" dan menggugah semangat para penggemar di kalangan muda. Sementara, kalangan tua merasa bahwa musik rock yang keras dan musik jazz yang akornya miringmiring akan mengganggu pendengaran dan perasaan. Juga orang tua khawatir dampaknya bagi perkembangan anak.

Karena itu, untuk pembelajaran dan penjelajahan diri, musik klasik terbukti lebih mampu menggugah otak dan menjangkau jiwa kita yang lebih dalam. Lozanov menandaskan "pada prinsipnya, musik klasik diciptakan untuk menanamkan pengaruhnya melalui filosofinya yang ramah, yang diungkapkan dalam bentuk yang sempurna. Di dalam tubuh manusia, musik klasik menciptakan kondisi yang dibutuhkan, yang secara alamiah mampu mengubah kekacauan dan disharmoni menjadi keteraturan, harmoni, konsistensi, logika, insipirasi, dan kegembiraan. Prinsip penciptaan musik klasik juga mampu menciptakan kondisi yang dibutuhkan sehingga terjadi kondisi relaksasi jiwa yang alamiah dan kondisi pikiran, yang darinya kapasitas- kapasitas cadangan ditampilkan dan dikeluarkan."

Seorang peneliti lain, Diamond (Merritt, 2003:77), percaya bahwa lagu ingar bingar bisa menuntun tubuh pada kondisi panik, stres, dan perilaku hiperaktif dan tidak tenang pada anak. Saraf mereka tertekan dan energi anak-anak lelah dan tidak enak badan. Menurut Diamond, banyak murid yang prestasinya meningkat setelah mereka meninggalkan kebiasaan mendengarkan musik rock saat menyelesaikan tugas sekolah.

Sebuah penelitian yang dilakukan oleh Tim Valifornia University (Republika, 11 Mei 2003), menyimpulkan bahwa orang yang mendengarkan sonata untuk 2 (dua) piano dalam D mayornya
Mozart, 10 menit sebelum mengerjakan tes, ternyata hasil tes mereka lebih tinggi dibanding dengan yang tidak mendengarkan sama sekali.

\subsubsection{Musik Klasik: Suatu Pilihan Alternatif}

"Musik ..... tidak boleh merusak telinga, musik harus menyenangkan pendengarnya." Artinya, dia tidak boleh berhenti menjadi musik, begitu kata Wolfgang Amadeus Mozart.

Apabila orang tua memperhatikan apa yang dikatakan Mozart, tentu akan memilih dengan hatihati jenis musik yang paling cocok untuk anakanak.

Dalam beberapa referensi, banyak ahli yang menganjurkan memilih jenis musik klasik, karena musik ini memiliki harmoni dan melodi yang baik; berpotensi untuk meningkatkan pengetahuan diri dan pengembangan diri, dan memiliki kekuatan yang besar untuk mengetuk sumber kreativitas anak. Musik klasik memberikan pengaruh positif bagi anak, baik perkembangan fisik maupun psikologisnya, karena musik klasik mengutamakan keteraturan, kecermatan, dan ketelitian. dan aransemennya mengandalkan kesatuan yang tertuju pada pengembangan.

Para peneliti di Barat (Republika, 08 September 2002:14) melaporkan bahwa instruksi dalam musik mempunyai peran positif dalam kemampuan anak belajar di bidang lain. Menurut mereka, anak yang belajar piano, baik dalam aktivitas penalaran spasialnya. Pemahaman spasial dan pemahaman hubungan sebagai suatu keseluruhan berkaitan dengan banyak kemampuan intelektual. Dalam aktivitas musik, anak dibiasakan bekerjasama dalam tim. Ini terjadi jika tergabung dalam grup ensambel, dan anak sudah mulai belajar tanggung jawab, dan membiasakan diri dalam jamaah.

Kemudian Lozanov (Merritt, 2003:5) pengembang metode belajar bebas stres accelerated learning memperkenalkan metode mengajar dasar-dasar percakapan bahasa Spanyol dalam 24 kali pertemuan. Di dalam sistem itu diperdengarkan musik klasik, permainan, lagu, dan drama, sehingga pelajaran terasa menyenangkan dan berhasil. Setelah menerapkan sistem itu, pada beberapa kelas terdapat perubahan kepribadian yang mencolok 
pada beberapa siswa. Siswa yang tadinya pemalu dan tertutup mulai membuka diri. Siswa yang semula agresif mulai bersikap lembut dan bisa berkomunikasi dengan siswa lain secara lebih hangat. Mereka juga melihat bahwa mereka bisa kreatif penuh imajinasi, spontan, dan peka.

Selain itu, yang lebih penting lagi adalah bagaimana orang tua memberikan arahan kepada anak ketika anak itu mendengarkan atau memainkan alat musik, karena mendengarkan suara musik dan memainkan alat musik yang dipaksakan dan tidak disukainya akan menimbulkan "ketidaknyamanan" si anak, meski sebenarnya anak itu tampak memiliki bakat.

\section{Daftar Pustaka}

Al-Baghdadi, Abdurrachman. 2001. Seni dalam Pandangan Islam. Jakarta: Gema Insani Press.
Ekomadyo, Ike Junita. 2005. 22 Prinsip Komunikasi Efektif untuk Meningkatkan Belajar Anak. Bandung: Simbiosa Rekatama Media.

Hardjana, Suka. 1983. Estetika Musik. Jakarta: Depdikbud.

Jensen, Eric. 1996. Brain Based Learning, Turning Point Pub., Del Mar, CA, USA

Merritt, Stephanie, 2003. Simfoni Otak, terj. Hala Herawati Dharma, Kaifa, Bandung.

Rakhmat, Jalaluddin, 2004. Psikologi Komunikasi. Bandung: Remaja Rosdakarya.

Tambunan, Marsha, 2004. Sejarah Musik dalam Ilustrasi. Jakarta: Progres,

Yahya, Wildan. 2004. Strategi Dakwah Islam dalam Pengembangan Seni dan Peradaban, Jurnal Komunikasi Mediator Fikom Unisba, Vol. 1 